\title{
Rising With the Robots: Towards a Human-Machine Autonomy for Digital Socialism
}

\author{
Christopher M. Cox
}

The University of Akron, Akron, OH, USA, ccox@uakron.edu

\begin{abstract}
This essay is concerned with conceptualising digital socialism in two ways. First, this essay typifies digital socialism as a real utopian project bringing together the utopian potential of "full automation" as tied to socio-economic imperatives indicative of socialist aims. Second, in recognition of a critical gap between full automation and an emerging technological autonomy, this essay argues for a human-machine autonomy that situates autonomy as a shared condition among humans and machines. By conceiving of humans and automated technologies as autonomous subject aligned against capital, pursuing the aims of digital socialism can anticipate and avoid capitalist ideologies that hinders possibilities for autonomous pursuit of digital socialism.
\end{abstract}

Keywords: digital socialism, robots, robotics, fully-automated communism, full automation, human-machine autonomy, Autonomist Marxism, Autonomism

\section{Introduction}

This essay attempts to answer the question "how do recent debates about 'full automation' and postcapitalist socioeconomics establish a foundation for conceptualizing digital socialism?"

Since 2015 , debates about socialism have exhibited a resurgence among public consciousness and electoral politics in the western world. From the election of "Marxadmiring socialist" (Danner 2015) Jeremy Corbyn as leader of the UK Labour Party to successive Bernie Sanders U.S. presidential campaigns foregrounding "democratic socialism" as a series of comprehensive socio-economic reforms aimed at creating an economy that "works for all, not just the very wealthy" (Frizell 2015) to the surge of 13,000 new members and 100 new chapters of the Democratic Socialists of America (DSA) (Schwartz 2017), "socialism" is increasingly mobilized by political actors.

Concurrently, the emergence of Jacobin as the "leading intellectual voice of the American left" (Matthews 2016) and the publication of The Socialist Manifesto: The Case for Radical Politics in an Era of Extreme Inequality by Jacobin founder Bhaskar Sunkara (2019) - and its coverage in mainstream news outlets from Wall Street Journal (Swaim 2019) to Slate (Weissman 2019) - have contributed to "more interest in and support for - socialist ideas than at any time in recent American history" (Nichols 2015, xxv).

Alongside increasing socialist consciousness and mobilisation, the latter part of the 2010s gave rise to the era of "automated connectivity" (Van Dijck 2013, 23), as automated processes built into digital platforms and techniques became significant forces in the production, governance, and maintenance of social life (Gillespie 2014; Bucher 2018). Since 2015, in tandem with the increasing interest in socialism, "full automation" has become increasingly central to imagining life beyond capitalism and thinking through the material means of reconstituting the production and provisioning of labour, goods, and services. 
To better understand the relationship between contemporary automation and socialism, this essay teases out critical strands among recent scholarship to, first, define the imperatives of "digital socialism" and, second, interject concerns for technological autonomy otherwise neglected among full automation debates. In doing so, the essay argues for digital socialism to be understood as a "real utopian" (Wright 2010) project, outlines the imperatives of digital socialism, and stresses the opportunity to conceive of autonomy as a shared condition among humans and machines to better solidify and anticipate class solidarity amidst the struggle to achieve socialist ends. The essay proceeds as follows:

- Digital Socialism: Full Automation as Real Utopia (section 2)

- Socialist Imperative 1: Shifting Values and Ethics Associated with Labour (section 3)

- Socialist Imperative 2: Centralised Planning (section 4)

- Socialist Imperative 3: Basic Services (section 5)

- Digital Socialism: Strategic Imperatives and Critical Opportunities (section 6)

- Dualities of Autonomy: Oppositions Between Human and Technological Autonomy (section 7)

- Becoming AutonomoUS: Human-Machine Autonomy (section 8)

- Human-Machine Autonomy and Solidarity Against Capital (section 9)

\section{Digital Socialism: Full Automation as Real Utopia}

Socialism is a socio-economic system predicated on maximising cooperation, democratic participation, and egalitarian outcomes in all spheres of life. Communism is a successive stage of the socialist project that enables all property and means of production to be held in commons (i.e. communally-owned), basic necessities to be apportioned based on a person's needs, and a centralized source (often conceived as the government) to maintain the mechanisms for communal ownership and equitable distribution. In and outside the United States, the terms "socialism and "communism" tend to be equated with Maoism, Stalinism, and other national communisms that installed totalitarian ideologues who amassed and wielded power through a form of "state capitalism" (Sperber 2019) ill-suited to ennobling the proletariat and resolving class struggle through democratic participation. On this front, the contemporary promulgation of "socialism" is at least somewhat attributable to the fact that it is no longer subject to "the burden of being associated in the propaganda systems of East and West with Soviet tyranny" (Chomsky 2016), a circumstance that enabled the East to maintain power through the aura of socialist aims and the West to demonize socialism and communism outright.

Socialism has led been associated with utopian thought, leading Engels to distinguish between utopian socialism (prominent in the $19^{\text {th }}$ century) and the historical materialism of Marx's "scientific socialism" (Engels 1880). Utopia is a broad term that encompasses a range of ideas about idealised conditions for society. In most cases, utopia is a place, one that is less a physical destination and more of a hypothetical realm where a harmonious society can be realised. Utopianism, in this sense, is a mode of thinking that attempts to imagine the conditions enabling social harmony, particularly in the context of governmental and economic relations. Utopian socialists in the 1880s attempted to foster social harmony by "devising plans to make society more cooperative, production more efficient, and distribution more fair" (Paden 2002, 68). These plans did not account for class politics and struggle and thus, for Marx and Engels, 
failed to represent the interests of any class, much less the proletariat forced into inevitable contact with capitalist ownership (Paden 2002, 68). For Engels (1880), then, "scientific socialism" entails similar ideas about cooperation and equity rooted in "the materialistic conception of history and the revelation of the secret of capitalistic production through surplus-value" (305) such that socialism is primarily concerned with "the necessary outcome of the struggle between two historically developed classes the proletariat and the bourgeoisie" (304).

Others attempt to mitigate the ethereal qualities of utopianism with a more pragmatic perspective on concrete political relations. Notably, Ernst Bloch focused on the spiritual aspect of utopia and the ability for political change to alleviate material burdens that undermine spiritual fulfilment in lived experience. For Bloch, utopia entails "the world of the soul, the external, cosmic function of utopia, maintained against misery, death, the husk-realm of mere physical nature" (Bloch 1918/2000, 3) [emphasis in original]. Bloch's utopianism is not an exotic hideaway or a proverbial Shangri-La but an inward journey of reflection and recognition of the universal conditions underlying the disillusion and disaffection experienced by many in modern capitalism. By reflecting on this spiritual condition of modern life, the journey inward illuminates the potential for a "utopian reality" (Bloch 1918/2000,179) envisioned as the ability to strive for a realm of fulfilment capable of being actualized in the material world. The recent emergence of a "real utopia" works from a similar register.

As devised by Erik Olin Wright, a "real utopian" project seeks practical opportunities to restructure social institutions to instantiate alternatives to capitalism and materialise "radical democratic egalitarianism" $(2010,22)$. By anchoring the large-scale optimistic imaginings of utopian thinking with "specific proposals for the fundamental redesign of different arenas of social instructions" and "immediately attainable reforms of existing practices" (Wright 2010, ii), real utopianism pursues new models for egalitarian practice predicated on their viability and achievability. While Marx and Engels criticise utopian socialists for a reactionary tendency to appeal to working masses with a religious zeal that harkens towards "castles in the air" rather than grounded political struggle $(1848,516-517)$, the real utopian project squares the circle by situating utopian visions as an outward projection from the fruits of viable material intervention. In doing so, discourses around full automation conceive of automated technologies as "vectors for new utopias" (Hester 2018, 8) and oppose the seeming unfeasibility and immobility of revolutionary traction, calling for "the futural orientation of utopias" combined with "real tendencies of the world today" to devise a feasible starting point for life beyond capitalism oriented towards continued progress and development (Srnicek and Williams $2015,108)$. In this way, contemporary ideas about full automation epitomise the spirit of real utopianism by, first, specifying contemporary conditions that make economic and social reconfigurations strategically viable and, second, leverage "full automation" as frame for utopian imaginings.

As a real utopian project, the emerging digital socialism seeks to avoid the technological determinisms often associated with the "California ideology") (Barbrook and Cameron 1996; Turner 2010) and other similar utopian ideas that stress free enterprise and marketplace expansion as the primary means of creating innovative technologies poised to change society for the better. Instead, real utopianism prioritises structural changes to policies and ideologies about the interrelationships of work, ownership, resource planning and allocation. By typifying the specifics of digital socialism as it emerges from debates about full automation from 2015-2019, the goal here is to clarify the lay of the land as it is, rather than argue for what it should be. Key works emerging during this timeframe include Inventing the Future: Postcapitalism and a World Without 
Work (Srnicek and Williams 2015), Four Futures: Life After Capitalism (Frase 2016), The Automatic Society: The Future of Work (Stiegler 2018), Xenofeminism (Hester 2018), Fully-Automated Luxury Communism (Bastani 2019), and Inhuman Power: Artificial Intelligence and the Future of Capitalism (Dyer-Witheford, Kjøsen and Steinhoff 2019). All of these monographs in their own ways and to varying degrees - engage with full automation in conjunction with describing socio-economic conditions necessary to imagine a postcapitalist world reflective of socialist aims (whether or not the term "socialism" is explicitly used). While I ultimately take up the task of more forcefully arguing for a solidified conception of human and technological autonomy, the first step is to collate and clarify the specifics of digital socialism as it currently stands. In doing so, I identity and specify three socialist imperatives significant to current ideas around full automation:

- Generating New Ethics, Values, and Arrangements for Labour

- Centralising Economic Planning

- Implementing Basic Services

\section{Socialist Imperative 1: Shifting Values and Ethics Associated With Labour}

In the case of the first socialist imperative, Srnicek and Williams $(2015,125)$ decry the capitalist work ethic's insistence that "renumeration be tied to suffering" and suffering the indignities and inequities of capitalist exploitation is "the only means for true selffulfillment". To their minds, the ability to implement full automation must account for the long-standing desire to attain status through work, even if said work is seen as undesirable. Significant cultural shifts around the work ethic can not only help underscore the possibilities for personal and collective fulfillment beyond market demands but also mitigate the precarity and turbulence of labour markets increasingly apt to diminish the abundance, variability, and remunerative sufficiency of work prospects. As a viable starting point, shortening the hours of the formal work week could reduce the amount of hours in the five-day week or institute a permanent three-day weekend (Srnicek and Williams 2015, 116).

In a similar vein, xenofeminism situates automation and other technologies as the means to reconfigure cultural notions of work. Xenofeminism is a recent strand of technofeminism that seeks to abolish the imposition of gender binaries and overturn essentialist gender ideologies associated with biological and social reproduction (Hester 2018). Xenofeminism's pursuit of gender abolition and anti-naturalism stresses "postindustrial automation" (Hester 2018,8) and related techno-materialisms as a means of changing concrete relations among gender, work, and social institutions (such as the family). Understood as a "multiply gendered world" (Hester 2018, 30), xenofeminsm's gender abolition seeks to enlarge the range of gendered expression and concomitantly undo expectations of domestic labour as tied to gender. Shifting cultural ideas about the constructed and contested nature of gender is part and parcel of undoing "culturally weaponised markers of identity that harbor injustices" (Hester 2018, 30), including the necessity of child labour as a potentially dangerous bodily labour undertaken by women and ensuing expectations around childrearing and domestic caretaking. Beyond undoing gender naturalism and expectations around domestic and biological labour, Hester offers Donna Haraway's (2016) notion of "kin" as a "means of prioritizing the generation of new kinds of support networks" (Hester 2018,63) to realise new forms of collaborative work and care, a "counter-social reproduction" envisioned as "social reproduction against the reproduction of the social as it stands" (Hester 2018, 64) [emphasis in original]. 
Offering full automation as an orienting force for collectivist formation and harmony, Bernard Stiegler (2018) situates capitalist automation as an entropic force that generates ever-increasing uncertainty, disorder, and instability in capitalist markets and society at large. These sentiments are internalised by everyday people who come to envision the future as inhospitable and devoid of the potential for widespread prosperity. For Stiegler $(2018,7)$, full automation is an opportunity for "dis-automatization", the harnessing of energies previously-dedicated to formal wage labour and recalibrated towards "collective investment of the productivity gains derived from automatization" (Stiegler 2018, 15) [emphasis in original], a collectivism predicated on a negentropic perspective that offsets the disarray of capitalism's automated entropy and engenders possibilities for egalitarian order and harmony. "Collective investment" also speaks to the need for economic and personal investment in work arrangements to be understood in terms of cooperation and plurality, eschewing the individualistic drives of capitalism to amass capital in defiance of the common good.

In their critique of full automation that foregrounds the role of artificial intelligence (Al), Dyer-Witheford, Kjøsen and Steinhoff's (2019, 153-156) "communist orientation to Al" attempts to reconfigure the relationship between postcapitalist futures and automated technologies. Rather than positing full automation as an opportunistic moment or tool to be seized and applied towards the break from capitalism, a communist orientation to Al prioritises "liquidating the structural dynamics of capital" (153) undergirding the development of automated technologies and the ethos built into these technologies by companies driven to patternise forms of social interactivity antithetical to socialist solidarity. To these authors' minds, the goal should be to expropriate capital from $\mathrm{Al}$, collectivise ownership of $\mathrm{Al}$, and retrain $\mathrm{Al}$ to function in accordance with collectivised values and structure to enact a "true democratization of Al" (Dyer-Witheford, Kjøsen and Steinhoff 2019, 154). Among such collectivised values, collectivised ownership is a central facet of the second strategic imperative of digital socialism.

\section{Socialist Imperative 2: Centralised Planning}

Similar to the way "full automation" is situated as a touchstone for charting a course beyond the confines of capitalism, "post-scarcity" is a similar touchstone among advocates of centralised planning (Frase 2016; Bastani 2019; Phillips and Rozworski 2019) who attempt to reconcile the technological ability to produce an uncapped abundance of goods and services with the artificial limits placed on production and dissemination by private ownership. Central planning entails a production of goods and services as directed by a governmental source to equitably allocate these goods and services. Even as some aspects of centralised planning receive more analysis than others, one of the recurrent themes among central planners is the ability to generate an abundance of goods and services equitability doled out through such planning, thereby transcending scarcity as a circumstance of private accumulation. One of the common threads about central planning advocacy is that forms of privatised central planning already in place are useful structures capable of being refashioned to equitably allocate resources.

One of the central tenets of Aaron Bastani's (2019) advocation for a fully-automated luxury communism is the necessity of demanding "the intentional, conscious planning at the heart of modern capitalism be repurposed to socially useful ends rather than socially destructive ones" (227). Bastani shows a particular concern for finance, foregrounding centralised banking and "municipal protectionism" (207) as two interrelated facets of central planning. Whereas central and private banks currently prioritise the administration of loans and other fiduciary mechanisms based on the assets held by a 
borrower and the likelihood of lending as a profitable venture, nationalised central banking shows the potential to guard against the inequities of capitalist finance by overseeing an informal network of locally-owned businesses and banks. In this context, "municipal protectionism" refers to the pursuit of localised businesses owned by workers that can better mitigate inequality through a wider range of ownership models (210). Tied to finance emanating from local banks and credit unions and mitigated by a centralised national bank tasked with ensuring equitable allocation, these types of businesses can protect against micro forms of capitalist domination within the workplace and macro forms of capitalist domination in society at large (211).

In Leigh Phillips and Michael Rozworski's (2019) monograph-length case study of Wal-Mart's internal central planning, they stress "openness and cooperation along the supply chain" as fundamental to planning and the ability to continuously replenish resources $(2019,38)$. By arguing for Wal-Mart's internal supply chain structure as a centralised mode of production and distribution predicated on collaboration and cooperation among participants, Phillips and Rozworski highlight institutional and political practices already at play that offer a viable means of recalibrating towards socialist ends. In their conception, central planning is not the purview of a small group of planners, programmers, or algorithmic calculations but, instead, relies on democratic participation at all points of production and consumption, if "computer-assisted, decentralized, democratic economic decision making" is to be realised (Phillips and Rozworski 2019, 213).

By treating the possibility of full automation and (post)scarcity as a given, Peter Frase (2016) outlines four possible future scenarios based on recomposed dualities of dualities of hierarchy/egalitarianism and scarcity/abundance: communism (egalitarianism and abundance), rentism (hierarchy and abundance), socialism (egalitarianism and scarcity), and exterminism (hierarchy and scarcity). Planning is but one of many facets impinging upon the extent to which resources are centralised for equitable allocation or concentrated for hierarchical control and, concomitantly, the extent to which resources are produced and replenished. Central planning and allocation also underlie efforts to instantiate and provide basic services.

\section{Socialist Imperative 3: Basic Services}

One of the most widely and frequently discussed ideas related to full automation is the possibility of a basic income (BI), often conceived as a universal or unconditional basic income (UBI). A basic income is the allocation of a nominal sum of money on a recurring basic to individuals who are not required to provide labour in exchange for this income. Much like the recent resurgence of socialist thought in mainstream political discourse, basic income is an old idea that has received considerable recent attention in correlation with full automation. Since 2015, a veritable cottage industry of popular press and trade books have outlined the case for basic income (Stern 2016; Van Parijs and Vanderborght 2017; Bregman 2017; Lowery 2018), with UBI serving as a cornerstone of Andrew Yang's 2020 presidential campaign (Yang 2019).

Advocacy for (U)BI tends to stress the increased power workers can enjoy when economic livelihood is not solely tied to wage labour, often stipulated as a necessary condition to address the diminishing need for human labour amidst the rise of full automation. With a UBI in place, workers could potentially choose not to work for certain periods of time, thereby increasing their individual negotiating power and the holistic power of labour (Srnicek and Williams 2015, 120). So long as it is sufficient to provide basic sustenance, allocated unconditionally, and a supplement to welfare programs 
(rather than a replacement), the working class can experience greater "voluntary flexibility" as opposed to precarity, instability, and insecurity (Srnicek and Williams 2015, $119 ; 212)$. At the individual level, UBI could function as a mechanism for providing universal access to resources while guarding against overuse (Frase 2016).

Criticisms of UBI stress the possibility of UBI as a salve to libertarian and neoliberal ideologies intent on replacing welfare programs with a lump monetary sum, a "full marketization of the welfare state" (Bastani 2019, 225). The concern is that pairing UBI with full automation does not alter the relationship between ownership and labour and, rather than augmenting the power of labour against ownership, risks a "miserable penury" for people whose labour potential is seen as useless and cordoned off from further economic and social mobility (Dyer-Witheford, Kjøsen and Steinhoff 2019, 150-151).

In addition to Srnicek and Williams insisting on UBI as a supplement to welfare programmes, Bastani $(2019,215,217)$ accounts for UBI as a compliment to five essential basic services provided on an unconditional basis: housing, transport, education, healthcare and information, wherein "information" is understood as "media production and connectivity". Under Bastani's model, the state plays an indispensable role in "procurement with local worker cooperatives building homes, hospitals and schools as well as performing catering, maintenance, cleaning, and support services," indicating a continued role for private ownership with the caveat "the leverage of anchor institutions will only expand", given the role of worker-owned businesses more suited to address the common good (217).

\section{Digital Socialism: Strategic Imperatives and Critical Opportunities}

At this point, we can now more specifically sketch "digital socialism" as a real utopian project advocating for full automation as a utopian beacon enjoined with the viable and practical pursuit of the following:

- Generating New Ethics, Values, and Arrangements for Labour

- Undoing the capitalist work ethic and gendered associations with domestic labour

o Shortening the formal working week

- Pursuing collectivity as a means of instituting social harmony, reshaping institutional arrangements, and ensuring collectivist values can be built into automated technologies

- Centralised Planning

- Planned allocation predicated on democratic participation from contributors and recipients of goods and services

- A network of localised worker-owned businesses, banks, and financial services operating under a "municipal protectionism" that guards against capital flight

- Central federal banking that supports and protects localised businesses and finance

\section{- Basic Services}

- Universal access to publicly-developed education, transport, housing, healthcare, and media connectivity and production

- A basic income apportioned unconditionally as a supplement to universallyavailable basic services 
From this foundational point, the foremost opportunity in pursuit of these goals is to ensure ideas about the relationship of full automation to socialist imperatives do not fall into traps laid by cultural ideas about the nature of autonomy and technological autonomy as an inevitable threat to workers.

\section{Dualities of Autonomy: Oppositions Between Human and Technological Auton- omy}

"Autonomous technology" refers to both a long-standing cultural fear about the social implications of technological progress and the functional ability for technologies to operate free from direct human intervention. In terms of the latter, degrees of automated capacity are often described in terms of technological autonomy. A fruitful example is self-driving cars, often referred to as "autonomous" cars. Levels of automation designated by the Society of Automotive Engineers (SAE) range from "zero autonomy" to "full autonomy" along a successive scale of automated capability running from zero to five (with zero as "no automation" and five as "full automation") (NHTSA 2019). Achieving full automation means that, in the case of self-driving cars, the vehicle can perform driving tasks that do not require a human to operate or intervene (although the technology may allow for human manual operation). As a cultural fear, autonomous technology refers to a belief that technology has "gotten out of control and follows its own course, independent of human direction" (Winner 1977, 13). One of the primary concerns of functional technological autonomy is the realisation of such fears as reinforced by pop culture depictions (i.e. the Terminator and Westworld franchises), mainstream news headlines declaring "The Future Has Lots of Robots, Few Jobs for Humans" (McNeal 2015), and popular press books such as Our Final Invention: Artificial Intelligence and the End of the Human Era (2013).

Even as recent scholarly discourse stresses the utopian potential of full automation, other pervasive cultural discourses about the dystopian "hegemonic" or "apocalyptic" implications of technological autonomy advance ideas about the possibilities for widespread social control or "agents of doom" posing an existential threat to human vitality (Nye 2004, 171). Where the cultural fear of autonomous technology is primarily "the question of human autonomy held up to a different light," (Winner 1977, 43), one of the primary fears about self-driving cars and other present-day autonomous technologies is the direct threat to posed to the autonomy of human labourers.

Books such as The Second Machine Age: Work, Progress, and Prosperity in a Time of Brilliant Technologies (2014) and Rise of the Robots: Technology and the Threat of a Jobless Future (2015) stress the increasing capability of intelligent machines to perform cognitive tasks once believed to be the unique purview of human intellect. Postulations about a forthcoming "automation wave" (Ford 2015) posit an impending tide of machines poised to "steal" the jobs of human labourers and threaten to deepen levels of socio-economic inequality as human workers are displaced - and replaced - in corollary with the escalation of automation towards technological autonomy. The threat to the autonomy of human labour supposed by technological autonomy epitomises many of Marx's concerns about strife and competition within the working class and the intensification of this circumstance when capitalist production pits machines against humans.

In Capital, Marx describes the labouring capacity of machines as pitted against human workers and, because of this competition: "The self-valorization of capital by means of the machine is related directly to the number of workers whose conditions of exis- tence have been destroyed by it" (Marx 1867, 557). Just as, with respect to commodities, "the devaluation of the world of men is in direct proportion to the increasing 
value of the world of things" (Marx 1844, 271) [emphasis in original], Marx posits a similar corollary relationship between humans and machines whereby the ability for human workers to seek and procure payment for their labour is invariably diminished the more ownership turns to machinic production. Ever the foresighted critic, Marx recognised that "machinery necessarily throws men out of work in those industries into which it is introduced, it may, despite this, bring about an increase of employment in other industries" (Marx 1867, 570). While technological innovation has historically led to the emergence of new industrial paradigms that reconfigure the types - rather than the amount - of labour required (Bastani 2019), the contemporary narrative that "this time is different" indicates an unprecedented and inalterable risk of permanent displacement due to the humanlike intelligence of increasingly autonomous technology (Brynjolfsson and McAfee 2014; Ford 2015).

Thus, despite the worthiness of drawing out the utopian potential of full automation amidst recent debates, such debates neglect the tendency of full automation to connote fearful notions of autonomous technology and what it portends for the potential of workers to direct their individual and collective capacities towards fruitful socio-economic gains. In this vein, foregrounding full automation risks reinforcing and unintentionally capitulating to Marx's concerns about competition between humans and machines and its potential to agitate intra-class strife among human workers. Applied towards socialist pursuits, the dichotomy between human and technological autonomy is a critical gap between the ability to imagine the utopian potential of full automation and pursue a democratic egalitarianism that can realise strategic imperatives that make full automation a viable venture.

To mitigate this gap, I offer human-machine autonomy (Cox 2018) as a conceptual frame for recognising that autonomy is not couched in a singular entity, be it human or machine. Within this mindset, understanding human-machine autonomy as a shared condition among humans and highly-automated technologies resists misconceptions about autonomy as an innately dominating force and capitulation to capitalist ideologies around labour and class composition. The next section unpacks aspects of autonomy amenable to this line of thinking, before pulling from autonomist Marxism theory to stress autonomy as a shared condition between humans and technologies and human-machine alignments against capital.

\section{Becoming AutonomoUS: Human-Machine Autonomy}

Ideas about technological and human autonomy as separate and discreet forces existing in negative correlation arise from illusory notions of autonomy as the sole province of an individualistic self. Autonomy is a "political or moral conception that brings together the ideas of freedom and control" often conceived as the ability to be "selfgoverning, independent, not ruled by an external law or force" (Winner 1977, 16). Scholars of technology and identity, however, reject the conception of an individual self as the source and purview of autonomous potential, particularly on the grounds that the autonomy of the self is a politics of domination. In her "Cyborg Manifesto", Donna Haraway problematises autonomy as emerging from the relationship between the self and the other. For Haraway, the self is one who is not dominated, a non-domination understood only in relation to the dominance of the other. The supposed ontological nature of the self is "to be autonomous, to be powerful" (Haraway 1990, 219). The ability to experience freedom and control is therefore tied to the ability to impose one's will onto others, a "tragedy of autonomy" that valorises the supremacy of the self through the domination of the other (Haraway 1990, 219). In their recent critique of technology as a "surrogate humanity", Atanasoski and Kalindi $(2019,136)$ attempt to 
further liquidate notions of autonomy in relation to a dominating self, citing the "myth of the autonomous human" as the product of a "racial fetish of post-Enlightenment thinking" emanating from colonialist histories built on subjugation and servitude and attendant notions of autonomy as a possibility for those who possess mastery and control over the subjugated and servile.

Such ideas about autonomy as a dominating self extends to technological autonomy, as the cultural fear of autonomous technology expresses itself as not only the loss of control over machines but as "the style of absolute mastery, the despotic, oneway control of the master over the slave" (Winner 1977, 20). Viewed through this lens, the fear of autonomous technology can be understood as bound up in the perceived inability for humans to dominate a technological other and the ability for a technological other to exert the same type of domination humans pursue through autonomous will.

In other words, for all that the illusory concept of autonomy as the purview of the self imparts about the politics of domination, one of the most critical points is that humans and technology share the same root conception of autonomy. Human and technological autonomy is not a matter of "here" and "there" but a shared condition inadequate to delineation along lines of a human or machine and, instead, invokes the same questions around the pursuit and application of power, freedom, and control. As Haraway notes, technology is not an object to be "animated, worshipped and dominated. The machine is us, our processes, an aspect of our embodiment" (Haraway 1990, 222). Where autonomy "cannot simply be understood as freedom from others" (Baker and Hesmondhalgh 2013, 40), these "others" include both human and machine counterparts. Moreover, instead of conceiving of autonomy as self-set life against or apart from an "other," recognizing that we are "socially constituted by others beyond themselves" (Baker and Hesmondhalgh 2013, 40) imparts of a sense of how our autonomous potential is truly a question of our autonomy. In other words, conceived in opposition to dualistic conceptions, autonomy is always a shared condition among humans and between humans and machines, even though autonomy is not equitably afforded or experienced. This does not entail a deterministic relationship, however, as economic relations, culture, legal frameworks, and other vectors constitute the circuity that gives human-machine autonomy its variable charge. Notions of autonomy with respect to capitalist relations and technology underscore human-machine autonomy as a shared condition among humans and machines the way capitalism organises and patternises possibilities for autonomy among ownership, workers, and machines.

Notably, Andrew Feenberg describes "operational autonomy" as a facet of capitalist ownership that incorporates autonomous potential into organisation, machinic, and workflow processes:

Operational autonomy is the power to make strategic choices among alternative rationalizations without regard for externalities, customary practice, workers' preferences, or the impact of decisions on their households. Whatever other goals the capitalist pursues, all viable strategies implemented from his peculiar position in the social system must reproduce his operational autonomy. The 'metagoal' of preserving and enlarging autonomy is gradually incorporated into the standard ways of doing things, biasing the solution to every practical problem toward certain typical responses. In industrial societies, strategies of domination consist primarily in embedding these constancies in technical procedures, standards, and artifacts in order to establish a framework in which dayto-day technical activity serves the interests of capital (Feenberg 2002,76). 
Understood in this light, capital implants self-serving notions of autonomy into processes that carry through to the fabric of material existence so that the autonomous potential of capital is reproduced and enhanced. To the extent that operational autonomy is a hegemonic imposition of capital, workers possess a counterhegemonic potential, a "reactive autonomy" that Feenberg $(2002,84)$ otherwise refers to as a "margin of maneuver". This reactive autonomy entails the ability of workers to leverage capitalist technology for the purposes of "controlling work pace, protecting colleagues, unauthorized productive improvisations, informal rationalizations and innovations" (Feenberg 2002, 84), and otherwise countervailing the operational autonomy of ownership. Reactive autonomy is a margin of manoeuvre because the degree to which workers exercise autonomy can expand or contract, as can the operational autonomy of capital. Much like autonomy among humans and technology, operational, and reactive autonomy are not bracketed off from one another and instead exist as co-constituted forms of autonomy inflecting upon on one another even though it is not supposed that reactive autonomy ever exceeds operational autonomy or reactive autonomy is the exemplar way for workers to attain and experience autonomy. Automation plays a variable role in this dynamic, as it

increases management's autonomy only at the expense of creating new problems that justify workers' demands for an enlarged margin of maneuver. That margin may be opened to improve the quality of self-directed activity or it may remain closed to optimize control (Feenberg 2002, 96).

To the mind of the capitalist, regardless of the degree of freedom or control afforded to labour, capitalist exchange "maximizes autonomy in general, promising liberation of the human essence from fixed definitions" (Feenberg 2002, 162), since ongoing acquisition and accumulation are infinite and therefore entail a range of shifting arrangements that increase both operational and reactive autonomy in the aggregate.

Of course, this does not hold up to baseline Marxian scrutiny, as reactive autonomy is an autonomy conceived and experienced only within the auspices of capitalist exploitation, alienation, and expropriation of surplus-value, as if operational autonomy was a natural phenomenon ensconced in some ineffable firmament and not the result of historical processes predicated on vouchsafing power and control in the hands of a dominant few. Nonetheless, reactive autonomy reinforces the central idea of humanmachine autonomy: autonomy is a shared condition experienced with varying intensities relative to critical socio-economic inputs shaping how autonomy is conceived, pursued, attained, and experienced. Furthermore, reactive autonomy shines a light on the autonomy of labour, understood by Autonomist Marxism as not only the autonomous potential of labour within capital, but the recognition that labour already possesses the ability to be autonomous from capital.

While the preceding stresses the autonomy of human-machine autonomy as one resistant to traditional notions of autonomy as the purview of the dominating self and, instead, a shared condition among humans and technology shaped by relations to production and other critical vectors, the final section draws from Autonomist Marxism to recalibrate a particular strand of Autonomist thought that considers technology as the means for capitalist domination and the autonomy of workers as the potential to overcome such technology through class conflict. Rather than positing capitalist technology as the dominating force, or the force that must be dominated, the goal in this final section is to reframe this argument in terms that seek to illuminate how dichotomies of human/technology and domination/control are apt to reinforce the individualistic drives 
of capitalist competition that pit workers against one another and fracture opportunities for solidified class struggle. Conceiving of autonomy as a shared condition among humans and machines emphasises the commonality already at hand among labour and the ability to draw from the shared potential for autonomy to maximise its potential in work arrangements and the overarching struggle against capital. By doing so, the ability to align full automation with strategic imperatives for socialism can evade technological dystopia, maximise utopian potential, and otherwise resist capitulation to strife among labour entities (human and machine).

\section{Human-Machine Autonomy and Solidarity Against Capital}

Autonomist Marxism is a branch of Marxian inquiry that affirms the potential of labour distinct from capitalist arrangements (Negri 2005; Berardi 2009; Tronti 1966/2000), foregrounding labour's "creative human energy" and the labourer as the "active subject of production, the wellspring of the skills, innovation and cooperation on which capital depends" (Dyer-Witheford 1999, 65). Autonomy, in this context, also refers to "labor's fundamental otherness from capital and also the recognition of variety within labor" (Dyer-Witheford 1999, 68). The variety within labour speaks to the recognition that capitalist labour is not a uniform series of functions and workers can strive for circumstances best suited to differentiated skills, innovation, and cooperation, even as wage labour imposes itself as in restrictive force for worker autonomy. Labour's "otherness" from capital, on the other hand, recognises the ability of the working class to exist apart from capitalism, while capitalism cannot exist without the working class. Since capitalism can only instantiate and maintain power through the institutionalisation of its aims, the autonomous potential of labour lies in a "non-institutionalized political power" unique to the working class (Tronti 1966/2000, 247), whose position as the subject of production entails an innate power unbeholden to institutional forms or the auspices of capitalist accumulation.

The Autonomist position on technology tends to correspond to the notion of autonomy as the grounds for domination. On one hand, technology is the means for capital to control and dominate workers while, on the other hand, capitalist technology is the thing that should be dominated, as through class conflict workers can upend capitalist technology and subsequently remake it in the image of socialist ends, leveraging the ability for workers' autonomous potential to break from capital and harness their "invention power" (Dyer-Witheford 1999, 69-71). From this perspective, Autonomist views of digital technologies reinforce the way emerging technologies are developed and deployed to be amenable to capitalist relations. In his description of the emerging "cognitariat", Berardi $(2009,35)$ cites digital technologies and network connectivity as giving rise to the ubiquity of cognitive labour performed without deference to formal work arrangements or social existence, a "creation of technical and linguistic interfaces ensuring the fluidity both of the productive process and of social communication". Matteo Pasquinelli's read on information technology entails a similar transformative process, with regard to Marx's organic composition of capital: "living information is understood as continuously produced by workers to be turned into dead information crystallized into machinery and the whole bureaucratic apparatus of the factory" (Pasquinelli 2015, $55)$.

In both cases, digital technology is conceived as a tool to exacerbate capitalist domination. Therefore, it should be surmounted by working class revolution. I do not necessarily quibble or find fault with these assessments but, rather, point out the opportunity for the Autonomist perspective to apply its foundational spirit to digital tech- 
nologies and recognise human-machine autonomy as an opportunity to consider political revolution as a coalition of human and technological workers based on their common subjectivity as labouring entities and the recognition for the mutual endeavours of humans and automated technologies to help realise the aims of digital socialism. If the original aim of Autonomist thought was to foreground the autonomy of workers as an inherent feature of class struggle, extending Autonomist thought outwards towards potential socialist futures demands consideration of another possibility: full automation need not be a choice between a tool to shed capitalist dominion or an inert infrastructure awaiting a political revolution to rewire its programming. Instead, a third option emerges: automated technologies as co-constituted with human workers and the working class. By understanding autonomy and autonomous production as a shared condition, human-machine autonomy can frame the struggle against capital as a form of solidarity among autonomous production undertaken across lines of human and technological performance based on their shared position against capital. This position is best illuminated through Mario Tronti's problematisation of a working-class ideology and the "strategy of refusal."

Tronti describes the unnecessity of developing an ideology unique to the working class, since the working class is a "a reality antagonistic to the entire system of capitalism", an ontological position that means workers exist irrespective to capitalism and are not inevitably bound to circumstances enabling the development and persistence of capitalist exchange (Tronti 1966/2000,6). The working class possesses the potential to exist beyond capitalism, whereas capitalism cannot exist without the exploitation of the worker. Should the working class accept the necessity of ideology, their struggle would become a "passive articulation of capitalist development" (7) [emphasis in original]. If the working class needs no ideology, and the pure fact of their autonomous production is sufficient, they are allied with machines as non-ideological and autonomous workers freighted with ideological dimensions by capital. Rather than conceive of technologies as allied with capital by virtue of their operational deployment against workers, we should recognise that ideology is neither a necessity for workers nor machines and both are subject to the imposition of capitalist ideologies with respect to the ways work is arranged and carried out.

Humans and automated technologies are both programmed to perform computational tasks carried out in accordance with the imperatives encoded into such programming (Bucher 2018). Computers are programmed via the input of computer code that dictates how to operate, just as human behaviour is directed by technological and social codes that impart ideas about how humans should operate. In the context of work, any worker striving to build the latest iteration of Al or leverage Al in formal work arrangements occupies an allied subjectivity with technology insofar as both are inflected with ideologies about capitalist work in spite of the shared unnecessity for ideology or work to be undertaken in accordance with capitalist principles. To attempt to break from capitalist technologies is to break from entities allied with workers, as this break is to affirm ideologies about the ontological existence of technologies and their "passive" position within capitalist orders. Further, to break from technology is to revert back towards the ideology of autonomy that insists upon domination as the means for political freedom. Extending Tronti's "strategy of refusal" offers a means to refuse ideological assumptions about autonomy and the split between the autonomous productivity of humans and machines.

The strategy of refusal acknowledges the ability for the working class to halt capitalist production by refusing to carry out capitalist demands or undertakings. Understood as both "the refusal to collaborate actively in capitalist development, [and] the 
refusal to put forward a positive programme of demands" (Tronti 1966/2000, 255), this strategy spotlights the autonomy of the working class to exist apart from capitalism and therefore use collective labour power as a means to advance the power of labour. Power, in this context, is the political power to recognise the autonomous potential to refuse capital and the power to cease productive activities that accord economic and social power to capital (Tronti 1966/2000, 256). By expanding the political valence of this refusal to consciously incorporate technological counterparts, the working class aligns all possible autonomous production as part of its refusal strategy and thwarts ideological ideas about autonomy as a source for domination and control. Solidarity with automated technologies, then, is not only possible; it is critical as a means of evading dystopian conceptions of technological autonomy, resisting ideological assumptions about autonomy, and undertaking political praxis geared towards maximising worker autonomy within capitalist as a means to move beyond its horizons.

\section{Conclusion}

While the preceding offers a foundation for typifying digital socialism and incorporating a human-machine autonomy that stresses the shared conditions humans and machines occupy with respect to capital, opportunities abound from this foundation. Scholars should consider relationships between eco-socialism (Pepper 2002; Huan 2014) and full automation, especially potential oppositions between raw resources necessary to develop such technologies and the environmental consequences of continued technological development. Additionally, while the politics of full automation largely corresponds to postcapitalist perspectives, Blockchain advocates imagine Blockchain automation as a source for Libertarian autonomy conceived as liberation from central banking and the state (Greenfield 2017; Swartz 2017), indicating a critical need to consider the Blockchain's decentralised structure and politics with an eye towards socialist imperatives.

To stress the utopian and joyous potential of digital socialism, human-machine autonomy should also be used to expand ideas around "acid communism" (Gilbert 2017; Fisher 2018). Acid communism is a "provocation and a promise" (Fisher 2018, 757) oriented towards recapturing the joyous spirit and harmonious possibilities of countercultural politics and lifestyle. Where neoliberalism established itself as a sensible form of individualism defined in contrast to ideas of collectivity and communal living emerging out of the 1960s counterculture, acid communism urges re-establishing countercultural pursuits for "the convergence of class consciousness, socialist-feminist consciousness raising and psychedelic consciousness, the fusion of new social movements with a communist project, an unprecedented aestheticisation of everyday life" (Fisher 2018, 758). It is, in other words, a recuperation and continuation of a cultural project otherwise stripped of its revolutionary potential and grouped into a libertarian ethos underpinning the emergence and global expanse of Silicon Valley (Turner 2010). Human-machine autonomy, then, can stress the collective reservoirs of autonomy already at hand for a collective consciousness that simultaneously seeks to stand down capitalist power imposition and uplift the ability to live a joyful life of meaningful pursuit indicative of Marxian aims for a worker's paradise.

\section{References}

Atanasoski, Neta and Kalindi Vora. 2019. Surrogate Humanity: Race, Robots, and the Politics of Technological Futures. Durham, NC: Duke University Press. 
Baker, Sarah and David Hesmondhalgh. 2013. Creative Labour: Media Work in Three Cultural Industries. London: Routledge.

Barbrook, Richard and Andy Cameron. 1996. The Californian Ideology. Science as Culture 6 (1): 44-72.

Barrat, James. 2013. Our Final Invention: Artificial Intelligence and the End of the Human Era. London: Macmillan.

Bastani, Aaron. 2019. Fully Automated Luxury Communism. London: Verso Books.

Berardi, Franco. 2009. The Soul at Work: From Alienation to Autonomy. Los Angeles, CA: Semiotext (e).

Bloch, Ernst. 1918/2000. The Spirit of Utopia. Redwood City, CA: Stanford University Press.

Bologna, Sergio. 1973. Class Composition and the Theory of the Party at the Origin of the Workers Councils Movement. London: Red Notes Collective.

Bostrom, Nick. 2014. Superintelligence: Paths, Dangers, Strategies. Oxford: Oxford University Press.

Bregman, Rutger. 2017. Utopia for Realists: And How We Can Get There. London: Bloomsbury Publishing.

Brynjolfsson, Eric and Andrew McAfee. 2014. The Second Machine Age: Work, Progress, and Prosperity in a Time of Brilliant Technologies. New York City: WW Norton \& Company.

Bucher, Taina. 2018. If... Then: Algorithmic Power and Politics. Oxford: Oxford University Press.

Chomsky, Noam. 2016. Interview - Noam Chomsky on Anarchism, Communism and Revolutions. Interview by C.J. Polychroniou. Truthout. Accessed Nov. 15, 2019. https://truthout.org/articles/noam-chomsky-on-anarchism-communism-and-revolutions/

Cox, Christopher. 2018. Autonomous Exchanges: Human-Machine Autonomy in the Automated Media economy. Accessed Oct. 26, 2019. https://scholarworks.gsu.edu/cgi/viewcontent.cgi?article $=1003 \&$ context=fmt dissertations

Danner, Chas. 2015. Jeremy Corbyn and the British Left's Rebellion. Intelligencer. Accessed Oct. 22, 2019. http://nymag.com/intelligencer/2015/09/jeremy-corbyn-and-the-british-leftsrebellion.html

Dyer-Witheford, Nick. 1999. Cyber-Marx: Cycles and Circuits of Struggle in High-Technology Capitalism. Urbana, IL: University of Illinois Press.

Dyer-Witheford, Nick, Atle Mikkole Kjøsen and James Steinhoff. 2019. Inhuman Power: Artificial Intelligence and the Future of Capitalism. London: Pluto Press.

Engels, Friedrich. 1880. Socialism: Utopian and Scientific. In MECW Volume 24, 281-325. London: Lawrence \& Wishart.

Feenberg, Andrew. 2002. Transforming Technology: A Critical Theory Revisited. Oxford: Oxford University Press.

Fisher, Mark. 2018. K-punk: The Collected and Unpublished Writings of Mark Fisher. London: Repeater Books.

Ford, Martin. 2015. Rise of the Robots: Technology and the Threat of a Jobless Future. New York City: Basic Books.

Frase, Peter. 2016. Four Futures: Life After Capitalism. New York City: Verso Books.

Frizell, Sam. 2015. Here's How Bernie Sanders Explained Democratic Socialism. Time. Accessed Oct. 22, 2019. https://time.com/4121126/bernie-sanders-democratic-socialism/.

Gilbert, Jeremy. 2017. Why the time has come for 'Acid Corbynism.' The New Statesman. Accessed Nov. 7, 2019. https://www.newstatesman.com/politics/uk/2017/10/why-timehas-comeacid-corbynism

Greenfield, Adam. 2017. Radical Technologies: The Design of Everyday Life. New York City: Verso Books.

Haraway, Donna. 2016. Staying with the Trouble: Making Kin in the Chthulucene. Durham, NC: Duke University Press. 
Haraway, Donna. 1990. A Manifesto for Cyborgs: Science, Technology, and Socialist Feminism in the 1980s. In Feminism/Postmodernism, ed. Linda J. Nicholson, 190-233. New York: Routledge.

Hester, Helen. 2018. Xenofeminism. Hoboken: John Wiley \& Sons.

Huan, Qingzhi. 2014. Eco-Socialism as Politics. New York City: Springer.

Kember, Sarah. 2003. Cyberfeminism and Artificial Life. London: Routledge.

Lowery, Annie. 2018. Give People Money: How a Universal Basic Income Would End Poverty, Revolutionize Work, and Remake the World. New York City: Crown Publishing.

Marx, Karl. 1867. Capital Volume One. London: Penguin.

Marx, Karl. 1844. Economic and Philosophical Manuscripts of 1944. In Marx \& Engels Collected Works (MECW) Volume 6, 229-258. London: Lawrence \& Wishart.

Marx, Karl and Friedrich Engels. 1848. The Communist Manifesto. Marx \& Engels Collected Works (MECW) Volume 6, 477-519. London: Lawrence \& Wishart.

Matthews, Dylan. 2016. Inside Jacobin. Vox. Accessed Oct. 16, 2019. https://www.vox.com/2016/3/21/11265092/jacobin-bhaskar-sunkara

McNeal, Marguerite. 2015. Rise of the Machines: The Future has Lots of Robots, Few Jobs for Humans. Accessed Oct. 27, 2019. https://www.wired.com/brandlab/2015/04/rise-machines-future-lots-robots-jobs-humans/

National Highway Traffic Safety Administration. 2019. Automated Vehicles for Safety. Accessed Oct. 27, 2019. https://www.nhtsa.gov/technology-innovation/automated-vehiclessafety

Negri, Antonio. 2005. The Politics of Subversion: A Manifesto for the Twenty First Century. Cambridge: Polity Press.

Nichols, John. 2011. The "S" Word: A Short History of an American Tradition... Socialism. London: Verso.

Nye, David. 2004. Technological Prediction: A Promethean Problem. In Technological Visions: The Hopes and Fears that Shape New Technologies, eds. Marita Sturken, Douglas Thomas and Sandra Ball-Rokeach, 159-176. Philadelphia: Temple University Press.

Paden, Roger. 2002. Marx's Critique of the Utopian Socialists. Utopian Studies 13 (2): 67-91.

Pasquinelli, Matteo. 2015. Italian Operaismo and the Information Machine. Theory, Culture \& Society 32 (3): 49-68.

Pepper, David. 2002. Eco-Socialism: From Deep Ecology to Social Justice. London: Routledge.

Phillips, Leigh and Michael Rozworski. 2019. The People's Republic of Wal-Mart: How the World's Biggest Corporations Are Laying the Foundation for Socialism. London: Verso.

Schwartz, Joseph M. 2017. A History of Democratic Socialists of America 1971-2017. Accessed Oct. 16, 2019. https://www.dsausa.org/about-us/history/

Sperber, Nathan. 2019. The Many Lives of State Capitalism: From Classical Marxism to Free-Market Advocacy. History of the Human Sciences 32 (3): 100-124.

Srnicek, Nick and Alex Williams. 2015. Inventing the Future: Postcapitalism and a World Without Work. New York City: Verso Books.

Stern, Andy. 2016. Raising the Floor: How a Universal Basic Income Can Renew Our Economic and Rebuild the American Dream. New York City: Public Affairs.

Stiegler, Bernard. 2018. Automatic Society: The Future of Work. Hoboken: John Wiley \& Sons.

Sunkara, Bhaskar. 2019. The Socialist Manifesto: The Case for Radical Politics in an Era of Extreme Inequality. New York City: Hachette UK.

Swaim, Barton. 2019. Political Books: The Rise of Equality Chic. Wall Street Journal, April 26. Accessed Oct. 22, 2019. https://www.wsj.com/articles/political-books-equality-chic11556290466

Swartz, Lana. 2017. Blockchain Dreams: Imagining Techno-Economic Alternatives After Bitcoin. In Another Economy Is Possible: Culture and Economy in a Time of Crisis, ed. ed. Manuel Castells, 82-105. Hoboken, NJ: Wiley. 
Tronti, Mario. 1966/2000. Workers and Capital. London: Verso.

Turner, Fred. 2010. From Counterculture to Cyberculture: Stewart Brand, the Whole Earth Network, and the Rise of Digital Utopianism, IL. Chicago: University of Chicago Press.

Van Dijck, José. 2013. The Culture of Connectivity: A Critical History of Social Media. Oxford: Oxford University Press.

Van Parijs, Phillippe and Yannick Vanderborght. 2017. Basic Income: A Radical Proposal for a Free Society and a Sane Economy. Cambridge, MA: Harvard University Press.

Weissman, Jordan. 2019. Should the U.S. Trash Capitalism? Slate. Accessed Oct. 22, 2019. https://slate.com/business/2019/05/socialist-manifesto-bhaskar-sunkara-socialism-berniesanders.html

Winner, Langdon. 1977. Autonomous Technology: Technics-Out-of-Control as a Theme in Political Thought. MIT Press.

Wright, Erik Olin. 2010. Envisioning Real Utopias. London: Verso Books.

Yang, Wesley. 2019. What Andrew Yang Means. Washington Post. Accessed Oct. 26, 2019. https://www.washingtonpost.com/outlook/2019/10/25/what-andrew-yangmeans/?arc404=true

\begin{abstract}
About the Author
Christopher M. Cox

Christopher M. Cox, PhD is Assistant Professor of Communication and Converged Media at the University of Akron. Researching in the areas of digital media theory, political economy, and cultural studies, his work examines the industrial development of digital media platforms and automated media technologies.
\end{abstract}

